\title{
Modifikasi Unit Pemotong Mesin Pencacah Serat Tkks Menggunakan Silinder Pemotong Tipe Reel
}

\section{Modification Of Cutter Chopping Machine Unit Cutter From Palm Oil Bunches Using Reel Type Cylinder}

\author{
Junaidi, Adriansyah \& Elvis Adril \\ Jurusan Teknik Mesin Politeknik Negeri Padang Kampus Limau Manis Padang \\ Telp. 0751-72590 Fax. 0751-72576 Email: Junaidisyampoltek@ gmail.com
}

\begin{abstract}
Oil palm empty fruit bunches (OPEFB) are solid waste from the oil palm plantation industry with a fiber content of $\pm 70 \%$, and can be used as a composite board reinforcement. From the results of previous studies found that the mechanical properties of composite boards of OPEFB fibers between the left, middle and right parts occur very large differences, this situation occurs because the length of the fiber used is not the same between $3-10 \mathrm{~cm}$. The long fibers in addition to the adhesive mixing process are very difficult and long, also resulting in uneven strength of the boards on each side. The purpose of this study is to modify the design of the TKKS fiber chopping machine cutting unit using a reel type cutting cylinder, making the machine cutting unit, and testing the engine performance. From the results of engine design, the engine capacity is $\pm 85 \mathrm{~kg} /$ hour, the engine size is $110 \mathrm{~cm} \times 36.5 \mathrm{~cm} \times 49 \mathrm{~cm}$, the motor power is $2.5 \mathrm{HP}$ with a rotation of $1450 \mathrm{Rpm}$.

The components of the chopper unit consist of the chopper holder measuring $8 \mathrm{~cm} \times 15 \mathrm{~cm} \times 13 \mathrm{~cm}$, placed 3 pieces of planers which are $8 \mathrm{~cm} \times 5 \mathrm{~cm} \times 0.4 \mathrm{~cm}$, the chopper shaft measuring $40 \mathrm{~cm}$ long and $\varnothing 3 \mathrm{~cm}$, the holder of the pin measuring $\varnothing 16 \mathrm{~cm}$ with a thickness of $0.6 \mathrm{~cm}$. From the results of engine performance testing, it is found that the capacity of the machine with $5 \mathrm{~mm}$ filter diameter is $35 \mathrm{~kg} /$ hour, diameter of $10 \mathrm{~mm} 48 \mathrm{~kg} /$ hour, diameter $15 \mathrm{~mm} 55 \mathrm{~kg} /$ hour and diameter of $20 \mathrm{~mm}$ is $65 \mathrm{~kg} /$ hour. The uniformity of the results in the filter hole $5 \mathrm{~mm}$ the average fiber length of $15-25$ is $80 \%$, the filter hole $10 \mathrm{~mm}$ fiber length an average of 30-40 $\mathrm{mm}$ by $82 \%$, the filter hole $15 \mathrm{~mm}$ fiber length an average of $40-50 \mathrm{~mm}$ by $85 \%$, and the filter hole $20 \mathrm{~mm}$ in fiber length an average of $50-60 \mathrm{~mm}$ by $80 \%$.
\end{abstract}

Keywords: composite; TKKS fiber, enumerator, reel type

\section{PENDAHULUAN}

Tandan kosong Kelapa sawit (TKKS) merupakan limbah buangan dari pabrik pengolahan minyak sawit dengan kandungan seratnya $\pm 70 \%$, dapat dimanfaatkan untuk serat berkaret, matres, kasur, keset dan bahan baku produk papan komposit berbasis serat. Indonesia sebagai penyedia serat alam terbanyak khususnya serat TKKS, tetapi serat ini pemanfaatannya sebagai bahan dasar komposit untuk pengembangan produk komersial masih terbatas.

Penelitian tentang pembuatan papan komposit menggunakan bahan serat TKKS dengan beberapa bahan perekat telah banyak dilakukan, dari hasil pengujian sifat fisik dan mekanik papan komposit pada umumnya didapatkan kekuatan papan telah memenuhi standar SNI, walaupun begitu tiap-tiap papan antara bagian kiri, tengah dan kanan terjadi perbedaan sifat yang sangat besar, terutama sekali kekuatan lentur dan kekuatan tekan sejajar serat. Hal ini disebabkan karena proses penyebaran perekat yang tidak merata, sehingga ada beberapa bagian dari papan tersebut terlalu banyak perekatnya dan bagian lain sedikit. Keadaan ini terjadi karena serat yang digunakan panjangnya bervariasi antara 3$12 \mathrm{~cm}$. Serat yang panjang disamping proses pencampuran perekat sangat susah dan lama juga mengakibatkan kekuatan papan tidak merata tiap-tiap sisi.

Dari hasil sebelumnya telah dibuat mesin pencacah serat TKKS sistem hammer mill dengan batang-batang pemukul berputar secara horizontal. Batang pemukul pada bagian sisi atas, kiri dan kanan 
dilengkapi dengan pisau ketam sebagai pemotong serat, dan pada permukaan atas dari rumah mesin dilengkapi pisau tetap sebagai penahan beban pada saat pemukul berputar memotong. Mesin bekerja secara kontinyu pada awal pemotongan, tetapi pada saat bahan serat semakin lama semakin banyak dimasukkan, putaran mesin terhenti. Hal ini disebabkan batang bergerak dan posisinya tidak tetap, sehingga mengakibatkan pisau-pisau ketam yang terpasang pada batang pemukul tidak banyak memotong, sering slip karena bahan serat liat.

Untuk mengatasinya, kajian perlu dilakukan untuk memodifikasi mesin pencacah serat TKKS dengan menggunakan silinder pemotong tipe reel. Unit pemotong ini terdiri dari silinder yang berputar secara horizontal, pada permukaannya dipasang secara memanjang pisau pemotong tipe reel (pisau tidak tetap), sedangkan pada tepi kiri dan kanan silinder terpasang pisau tetap (bedknife) yang akan menahan tekanan geser dari pisau tidak tetap pada saat serat akan dipotong. Penggunaan tipe unit pencacah ini telah banyak digunakan untuk memotong bahan pertanian yang liat dan berserat dan bahan plastik. Wahyu. K (2011) dalam proses pencincangan sarasah tebu untuk dijadikan kompos. Mardison (2000) menggunakan pisau pemotong rumput tipe reel, memberikan hasil potongan rata pada bagian tajuk rumput yang dipotong sehingga tidak mengganggu pertumbuhan rumput. Pemotong tipe reel ini dapat mencacah plastik secara kontinyu dengan kapasitas $195 \mathrm{~kg} / \mathrm{jam}$, dengan keseragaman butiran $80 \%$ menggunakan komponen penyaring (Junaidi, 2015).

Tujuan penelitian ini adalah memodifikasi rancangan unit pemotong mesin pencacah serat TKKS mengunakan silinder pemotong tipe reel, membuat unit pemotong mesin, dan melakukan pengujian terhadap kinerja mesin.

\section{Serat Tandan Kosong Sawit}

Tandan kosong kelapa sawit (TKKS) merupakan salah limbah padat industri kelapa sawit dengan kandungan seratnya $\pm 70 \%$ dengan kandungan selulosa 37,76 \% (Darnoko dkk, 2001). Sebagai limbah lignoselulosa serat yang terkandung dalam TKKS dapat diuraikan (defiberasi) secara mekanis atau semi kimia. Bentuk TKKS dan seratnya seperti Gambar 1 dan Gambar 2.

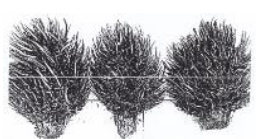

Gambar 1. TKKS

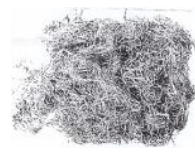

Gambar 2. Serat TKKS
Bila dibandingkan dengan kayu, kandungan lignin serat TKKS hampir sama, yaitu $23,13 \%$. yaitu $23,13 \%$. Beberapa sifat serat TKKS dibandingkan dengan serat sabut kelapa, kayu sengon dan akasia disajikan pada Table 1 .

Tabel 1. Perbandingan Sifat Serat TKKS, Kayu Sengon, dan Akasia

\begin{tabular}{|l|c|c|c|c|}
\hline \multicolumn{1}{|c|}{ Sifat } & $\begin{array}{c}\text { Serat } \\
\text { TKKS } \\
*\end{array}$ & $\begin{array}{l}\text { Sabut } \\
\text { kelapa* } \\
*\end{array}$ & $\begin{array}{l}\text { Kayu } \\
\text { Sengon**** }\end{array}$ & $\begin{array}{l}\text { Kayu } \\
\text { Akasia*** }\end{array}$ \\
\hline $\begin{array}{l}\text { Diameter } \\
(\mu \mathrm{m})\end{array}$ & 300 & $\begin{array}{c}100- \\
450\end{array}$ & 307,70 & 211,80 \\
\hline $\begin{array}{l}\text { Kandungan } \\
\text { seluosa }(\%)\end{array}$ & 47,81 & $37-43$ & 48,07 & 46,98 \\
\hline $\begin{array}{l}\text { Kandungan } \\
\text { lignin }(\%)\end{array}$ & 23,13 & $42-45$ & 21,58 & 22,40 \\
\hline
\end{tabular}

Sumber : * Kasim (2008)

**Nangia dan Biswas (2000)

*** Massijaya (1992)

\section{Serat Sebagai Penguat Papan Komposit}

Secara umum dapat dikatakan bahwa fungsi serat adalah sebagai penguat bahan untuk memperkuat komposit sehingga sifatsifatnya mekaniknya lebih kuat, kaku, tangguh, dan lebih kokoh bila dibandingkan dengan tanpa serat penguat. Ada 2 penggunaan serat dalam campuran komposit yakni serat pendek dan serat panjang. Dalam pembuatan komposit, serat pendek ini \pm (20-100) mm panjangnya. Serat pendek lebih mudah peletakkannya dibandingkan serat panjang, dengan orientasi yang benar akan menghasilkan kekuatan yang besar dibandingkan dengan serat panjang. Komposit serat pendek dapat diproduksi dengan cacat permukaan yang rendah sehingga kekuatannya dapat 
mencapai kekuatan teoritisnya (Schwartz, 1984).

Komposit serat panjang lebih mudah diorientasikan jika dibandingkan dengan serat pendek, walaupun begitu serat pendek memiliki rancangan yang lebih banyak. Secara teori serat panjang dapat menyalurkan suatu pembebanan atau tegangan dari suatu titik pemakaiannya. Perbedaan antara serat pendek dan serat panjang adalah serat pendek dibebani secara tidak langsung dan kekuatan atau kelemahan matrik akan menentukan dari sifat produk komposit tesebut, yakni jauh lebih kecil dibandingkan dengan besaran yang terdapat pada serat panjang (Hummaidi, 1998)

\section{Tipe Mekanisme Alat Pencacah}

\section{Alat Pencacah Kompos}

Alat pencacah kompos (Gambar 3) merupakan salah satu alat yang dapat membantu dalam proses pembuatan kompos secara anaerob dengan bahan baku khususnya sampah organik dengan memperkecil ukuran (Sudrajat 2006).

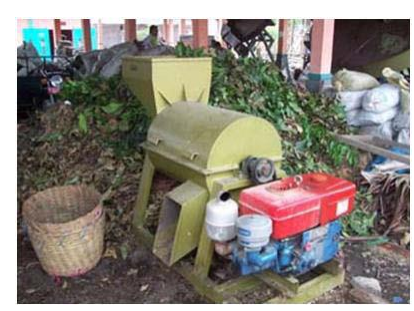

Gambar 3. Alat pencacah kompos (Sudrajat 2006

Sistem kerja alat ini pada dasarnya sama dengan gilingan martil (hammer mill). Menurut Kong Hwan Kim 1989 martil (hammer) pada mesin (hammer mill) berfungsi sebagai batang pemukul atau dapat juga diganti dengan batang pisau pemotong. Proses yang terjadi adalah bahan atau material seperti serat, dedaunan, sayuran dimasukkan ke dalam hammer mill yang berputar kemudian produk yang dihasilkan menjadi ukuran yang lebih kecil (size reduction).

\section{Tub Grinders}

Tub grinder (Gambar 4) adalah alat khusus yang digunakan untuk memotong/membelah (chopping) kayu termasuk di dalamnya batang dan dedaunan dalam jumlah yang besar. Sistem kerja dari tub grinder ini adalah sistem kerja pisau pemotong (hammer mill) yang bergerak secara horizontal

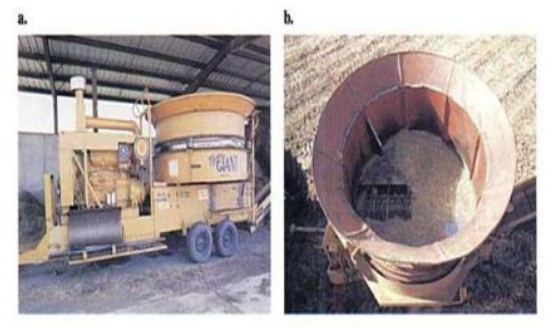

Gambar 4. Tub grinders (Robert 1995).

\section{Crushing}

Crushing adalah alat pencacah yang banyak digunakan pada bahan-bahan pertanian dan limbah-limbah padat yang bertujuan untuk memperkecil ukuran bahan, merusak struktur bahan untuk memudahkan pencacahan dan menghaluskan bahan dalam bentuk serbuk.

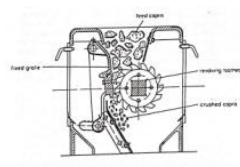

a

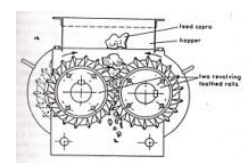

b

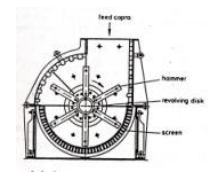

Gambar 5. Sistem Crushing pada Bahan Pertanian dan Limbah Padat (Thieme, 1969)

Keterangan :

5a. Pisau berputar secara horizontal pada satu poros (single roll)

5b. Pisau berputar secara horizontal dan tersusun pada dua poros (double roll) yang berputar berlawanan

5c. Alat pencacah terdiri dari palu-palu yang tersusun secara melingkar, sambil berputar palu-palu akan menghancurkan bahan secara berulang kali

Pada Gambar 5 adalah proses crushing pada kopra menjadi partikel kecil untuk memudahkan ekstraksi minyak dan akibatnya hasil akan meningkat. Crushing dilakukan dalam dua tahap. Pada tahap pertama adalah pencacahan kopra menjadi ukuran yang kecil berbentuk serpihan 


\section{Tipe Pisau Pemotong}

Pisau pemotong rumput dibedakan menjadi dua berdasarkan tipe pisau pemotong yaitu pisau pemotong rumput tipe reel dan tipe slasher.

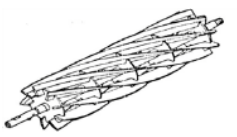

a. Tipe Reel

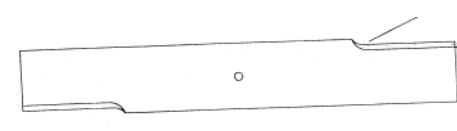

b. Tipe Slasher
Gambar 6. Jenis-jenis pisau pemotong rumput (Mardison 2000).

Pisau pemotong rumput tipe slasher terdiri dari satu bilah pisau yang digerakkan secara rotasi dengan kecepatan tinggi, sehingga menghasilkan daya pukul yang kuat untuk memotong rumput (Mardison 2000). Pisau pemotong rumput tipe reel memberikan hasil potongan rata pada bagian tajuk rumput yang dipotong sehingga tidak mengganggu pertumbuhan rumput. Pisau pemotong rumput tipe slasher memberikan hasil potongan yang tidak baik pada bagian tajuk rumput, di mana tajuk rumput bekas potongan jadi pecah dan hasil potongan tidak rata (Beard 1993).

\section{Metode Pemotongan Bahan Pertanian}

Pemotongan (Cutting) bahan bahan hasil pertanian sering dilakukan pada saat panen (harvesting), dalam pemisahan (separation) dan juga dalam proses pengecilan (comminution) ukuran bahan.

Pada saat pemotongan, mata pisau menembus ke dalam bahan, melewati kekuatan bahan sehingga bahan menjadi terpisah. Pada saat pemotongan berlangsung, terjadi perbedaan deformasi pada bahan, yang tergantung pada bentuk mata pisau dan proses kinematik pemotongan (Sitkey 1986). Gambar 7a memperlihatkan proses pemotongan yang menggunakan dua mata pisau yang saling berhadapan dan terlibat pemotongan (countermoving blade). Contoh untuk kasus ini adalah gunting. Gambar 7b memperlihatkan tipe alat potong di mana bahan diletakkan pada landasan yang diam dan pisau pemotong bergerak. Contoh praktis pada proses ini adalah pada perajangan keripik singkong dengan alat chipper. Gambar 7c mengilustrasikan pemotongan lapisan yang tipis, di mana distribusi tegangan di sekitar mata pisau mengalami distorsi yang sangat besar akibat permukaan bebas pada sekitar bidang pemotongan. Gambar 7d menunjukkan metode pemotongan bebas (free cutting) yang saat ini banyak dilakukan. Pada kasus ini kecepatan mata pisau harus tinggi (20 $40 \mathrm{~m} / \mathrm{s}$ ) (Sitkey 1986).

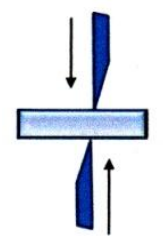

(a)

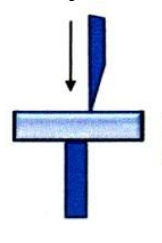

(b)

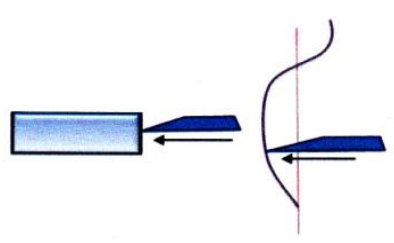

(c)

(d)
Gambar 7. Beberapa Metode Pemotongan (Sitkey 1986)

\section{Hasil Penelitian Tahun ke I}

Mesin pencacah serat TKKS yang telah dibuat sebelumnya dengan sistem Hammer mill menggunakan batang-batang pemukul berputar secara horizontal (Gambar 8). Batang pemukul pada bagian sisi atas, kiri dan kanan dilengkapi dengan pisau ketam sebagai pemotong serat, dan pada permukaan atas dari rumah mesin dilengkapi pisau tetap sebagai penahan beban pada saat pemukul berputar memotong. Kelemahan mesin adalah, kapasitas rendah $\pm 15 \mathrm{~kg}$ per jam, mesin sering tersendat (slip) terutama sekali pada saat bahan serat semakin lama semakin banyak dimasukkan putaran mesin terhenti. Hal ini disebabkan batang pemukul bergerak, sehingga mengakibatkan pisaupisau ketam yang terpasang pada batang pemukul tidak banyak memotong. Dengan keadaan ini tingkatan ukuran panjang serat yang diinginkan belum tercapai. 


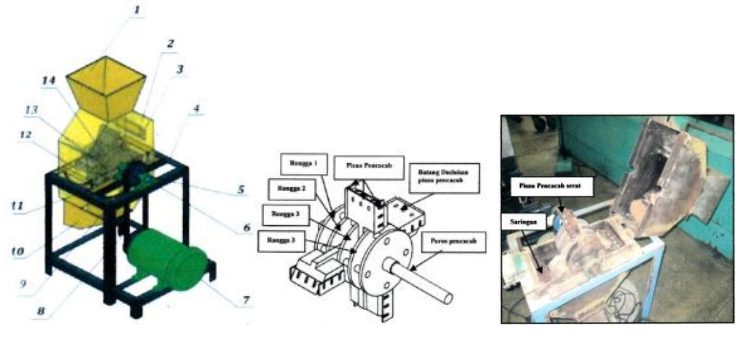

Gambar 8. Mesin Pencacah Serat TKKS Sistem Hammer Mill (Junaidi, 2017)

\section{METODOLOGI}

\section{Modifikasi Rancangan Mesin}

Modifikasi rancangan mesin dilakukan untuk memudahkan dalam pembuatan unit komponen yang akan dimodifikasi. Modifikasi mesin pencacah ini seperti pada Gambar 9.
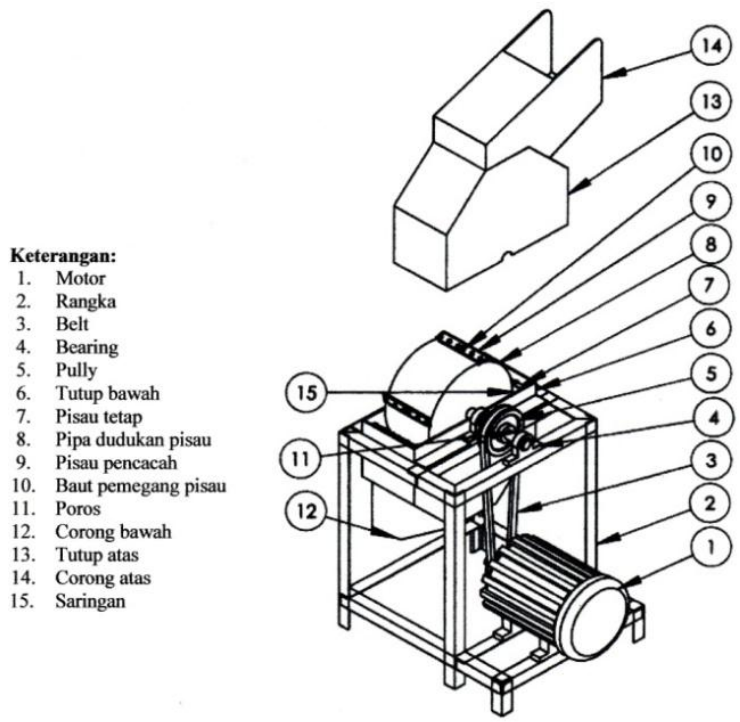

Gambar 9. Mesin Pencacah Serat TKKS Sistem pemotong Tipe Reel

Mesin pencacah serat memiliki empat unit komponen utama, yaitu unit pencacah, unit body, unit rangka dan unit penggerak. Unit pencacah terdiri pisau pencacah tidak tetap dan pisau pencacah tetap (bedknife). Pisau pencacah yang digunakan seperti pada Gambar 9 menggunakan pisau ketam yang ada dipasaran yang terbuat dari baja keras berukuran $8 \mathrm{~cm} \mathrm{x} 3$ $\mathrm{cm} \times 0,3 \mathrm{~cm}$ yang mempunyai sudut mata potong $30^{\circ}$ terpasang pada permukaan luar pipa berbentuk silinder (8). Pisau pencacah tidak tetap sebanyak dua buah dalam satu baris, dan dalam satu lingkaran sebanyak 4 baris sehingga jumlah pisau semuanya dalam satu lingkaran 8 buah, sedangkan pisau pencacah tetap terpasang pada sisi kiri dan kanan tutup bawah mesin yang masing-masingnya berjumlah dua buah.

Pemasangan pisau-pisau pencacah tidak tetap maupun pisau pencacah tetap pada dudukannya diikat dengan baut (10) sekuat mungkin agar tidak mudah berubah pada waktu adanya gaya pemotongan dari pisau pada waktu silinder berputar. Efisiensi proses pemotongan serat sangat ditentukan oleh posisi sudut pisau dengan permukaan luar silinder, sudut pisau pencacah, ketajaman pisau pencacah, kekuatan bahan pisau dan jarak ujung pisau tetap dan tidak tetap.

\section{Pembuatan Unit Pemotong Mesin}

\section{Pencacah}

Setelah rancangan mesin siap kemudian dilakukan pembuatan komponen dan assembling. Komponen-komponen mesin dipasang berdasarkan unit-unit yang ada pada mesin.

\section{Evaluasi Teknis}

Evaluasi teknis terhadap prototype akan dilakukan dibengkel mesin. Evaluasi dibengkel untuk mengidentifikasi kinerja bagian pisau pencacah, putaran mesin, ukuran panjang serat TKKS. Metode yang digunakan dalam pengujian kinerja ini adalah metode exsperimen, untuk tahap pengolahan data yang mana data yang diambil dihitung secara rataan dari pengujian, dimana pada satu kali pengujian akan menggunakan serat TKKS hasil penguraian secara mekanis. Beberapa perlakuan yang akan dilakukan pada proses pengujian yaitu :

- Kelonggaran antar pisau : Kelonggaran yang diberikan pada pengujian dengan 3 macam kelonggaran yaitu, $0,3 \mathrm{~mm}, 0,5$ $\mathrm{mm}$, dan $1 \mathrm{~mm}$.

- Besarnya lobang saringan: $5 \mathrm{~mm}, 10$ $\mathrm{mm}, 15 \mathrm{~mm}, 20 \mathrm{~mm}$. 


\section{HASIL DAN PEMBAHASAN}

\section{Hasil Modifikasi Unit Pencacah}

Modifikasi mesin pencacah serat TKKS ini dilakukan pertama sekali pada unit pencacah, yaitu membuat dudukan pisau pencacah seefektif mungkin agar pisau pencacah bisa kokoh dudukannya dan pisau bisa memotong dengan kuat. Untuk mendapatkan dudukan pisau pencacah pertama sekali piring pemegang pin pencacah ditambah diameternya $28,7 \mathrm{~cm}$ dengan mengelaskan plat bulat pada piring tersebut, setelah itu dibersihkan dengan mesin bubut (Gambar 10). Pemasangan pisau tidak tetap pada pipa silinder yang mana sebelumnya dipasang dudukan pisau dengan proses pengelasan sebanyak 4 buah, dan pemasangan pisau tetap pada tepi kiri dan kanan bodi bawah mesin. Selanjutnya dilakukan penyetelan jarak kelonggaran antara kedua pisau tidak tetap dan pisau tetap dengan jarak minimal 0,2 mm agar proses pemotongan serat cepat dan menghindari terjadinya slip (Gambar 11). Setelah itu dilakukan assembling keseluruhan dari mesin dan pengujian mesin dengan pencacahan serat dengan beberapa ukuran lobang saringan (gambar 12).
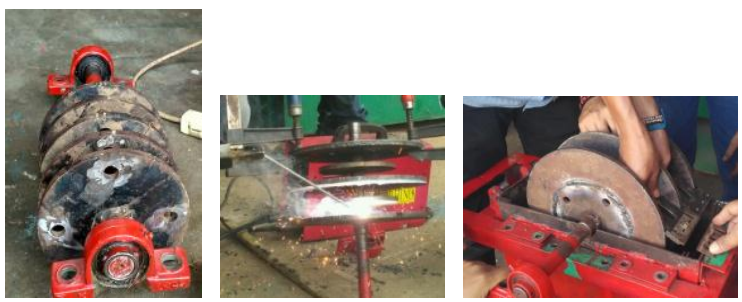

Gambar 10. Modifikasi unit pencacah
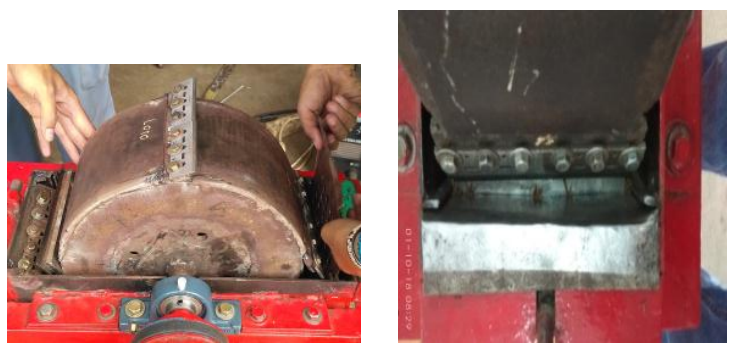

Gambar 11. Pemasangan pisau dan penyetelan kelonggaran pisau
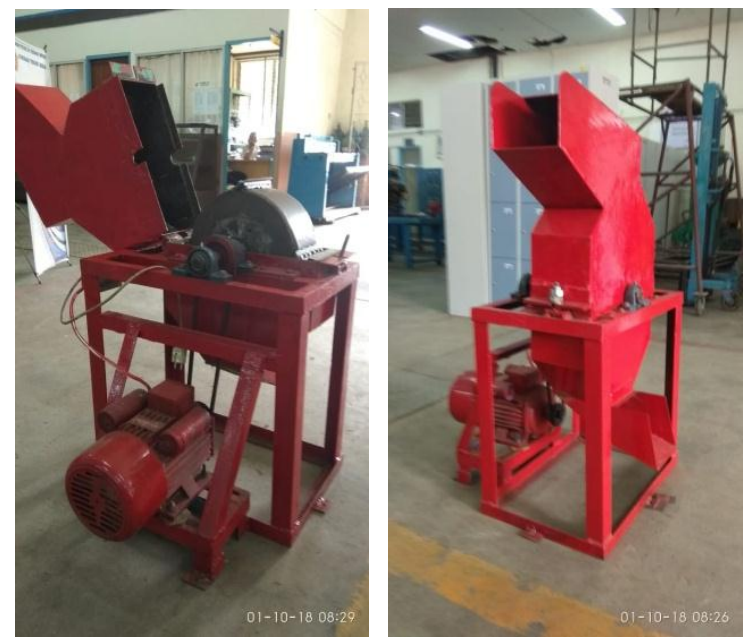

Gambar 12. Pemasangan bodi atas dan Assembling

\section{Pengujian Mesin}

Pengujian mesin dilakukan pada beberapa diameter lobang saringan untuk mendapatkan beberapa macam panjang serat. Beberapa diameter lobang saringan tersebut yaitu $\varnothing 5$ $\mathrm{mm}, 10 \mathrm{~mm}, 15 \mathrm{mmdan} 20 \mathrm{~mm}$, dan proses dari pengujian seperti pada Gambar 10. Hasil dari pengujian yaitu kapasitas mesin dengan diameter lobang saringan $5 \mathrm{~mm}$ adalah 35 $\mathrm{kg} / \mathrm{jam}$, diameter $10 \mathrm{~mm} 48 \mathrm{~kg} / \mathrm{jam}$, diameter $15 \mathrm{~mm} 55 \mathrm{~kg} / \mathrm{jam}$ diameter $20 \mathrm{~mm}$ adalah 65 $\mathrm{kg} / \mathrm{jam}$. Kapasitas mesin sebelum dimodifikasi dengan diameter lobang saringan $5 \mathrm{~mm}$ adalah $7 \mathrm{~kg} / \mathrm{jam}$, diameter $10 \mathrm{~mm} 10 \mathrm{~kg} / \mathrm{jam}$ dan diameter $15 \mathrm{~mm} 12 \mathrm{~kg} / \mathrm{jam}$ dan diameter 20 $\mathrm{mm} 15 \mathrm{~kg} / \mathrm{jam}$, dan mesin sering tersendat

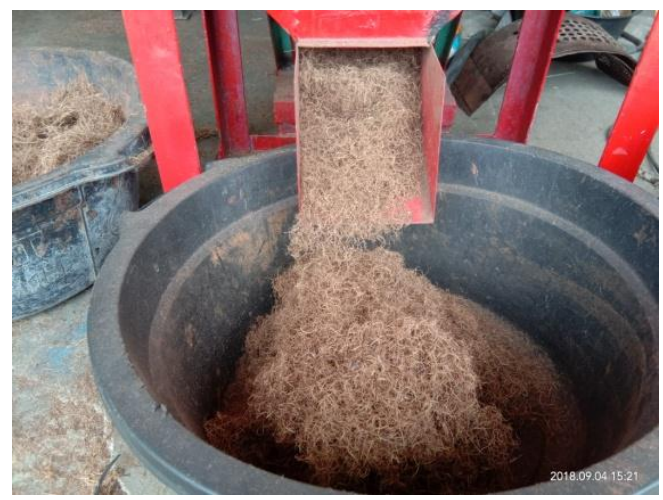

Gambar 13. Proses pencacahan serat

Dari hasil pengujian dengan beberapa tingkatan saringan tersebut didapatkan panjang serat dengan beberapa diameter lobang saringan seperti tabel 2 berikut: 
Tabel 2. Rata-rata panjang serat berdasarkan diameter lobang saringan

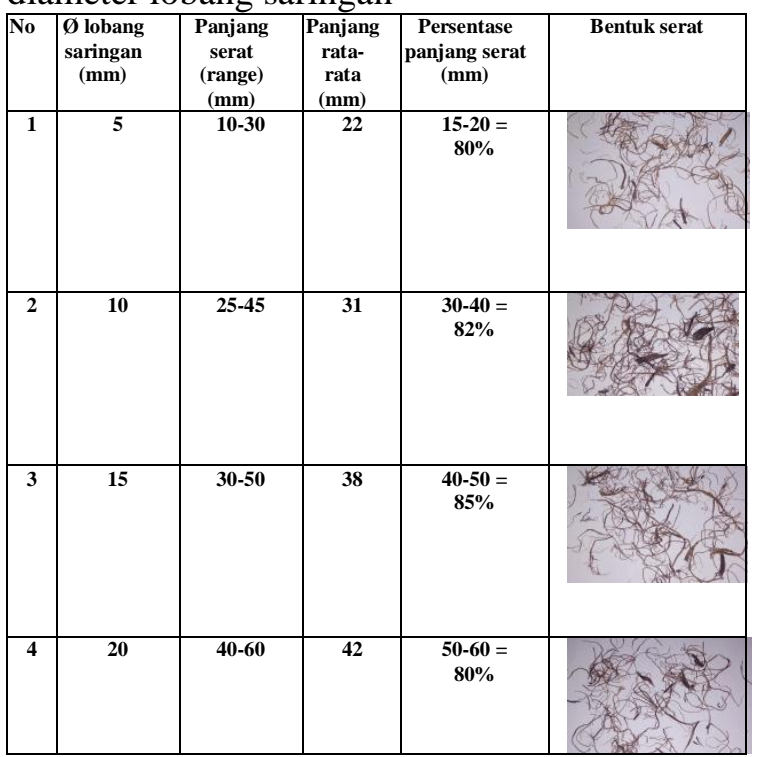

Berdasarkan hasil pengujian pada mesin pencacah serat, didapatkan hasil cacahan serat seperti pada tabel 2 pada diameter lobang saringan $5 \mathrm{~mm}$ didapatkan panjang serat rata-rata adalah $22 \mathrm{~mm}$, kisaran serat antara 10-30 $\mathrm{mm}$, dan persentase terbesar panjang serat rata-rata $15-20 \mathrm{~mm}$ sebesar $80 \%$. Dari pengujian ini terlihat kapasitas mesin semakin kecil karena lobang saringan kecil, serat di potong berulangkali sambil dibawa oleh pisau pencacah berputar dengan beberapa kali putaran sampai serat habis terpotong.

Pada diameter lobang saringan $10 \mathrm{~mm}$ panjang serat rata-rata $31 \mathrm{~mm}$, kisaran serat antara 25-45 $\mathrm{mm}$, dan persentase terbesar panjang serat rata-rata $30-40 \mathrm{~mm}$ sebesar $82 \%$. Pada diameter lobang saringan $15 \mathrm{~mm}$ panjang serat rata-rata $38 \mathrm{~mm}$, kisaran serat antara $30-50 \mathrm{~mm}$, dan persentase terbesar panjang serat rata-rata $40-50 \mathrm{~mm}$ sebesar $85 \%$. Selanjutnya pada diameter lobang saringan $20 \mathrm{~mm}$ panjang serat rata-rata 42 $\mathrm{mm}$, kisaran serat antara $40-60 \mathrm{~mm}$, dan persentase terbesar panjang serat rata-rata 50-60 mm sebesar $80 \%$.

\section{SIMPULAN}

Hasil kajian yang telah dilakukan telah dimodifikasi dan dibuat prototype mesin pencacah serat TKKS menggunakan silinder pemotong tipe reel, daya mesin 2,5
HP dengan putaran motor $1500 \mathrm{Rpm}$. Bagian utama mesin ini adalah : unit pencacah yang terdiri dari poros pencacah, pisau pencacah, batang dudukan pisau pencacah, pin, dan plat pemegang batang dudukan pisau. Unit corong terdiri dari corong masuk, corong keluar dan saringan, unit rangka dan unit penggerak. Berdasarkan hasil pengujian kinerja mesin pada diameter lobang saringan $5 \mathrm{~mm}$ didapatkan panjang serat rata-rata adalah 22 $\mathrm{mm}$, kisaran serat antara 10-30 $\mathrm{mm}$, dan persentase terbesar panjang serat rata-rata 15-20 mm sebesar $80 \%$. Pada diameter lobang saringan $10 \mathrm{~mm}$ panjang serat ratarata $31 \mathrm{~mm}$, kisaran serat antara $25-45 \mathrm{~mm}$, dan persentase terbesar panjang serat ratarata $30-40 \mathrm{~mm}$ sebesar $82 \%$. Pada diameter lobang saringan $15 \mathrm{~mm}$ panjang serat ratarata $38 \mathrm{~mm}$, kisaran serat antara $30-50 \mathrm{~mm}$, dan persentase terbesar panjang serat ratarata $40-50 \mathrm{~mm}$ sebesar $85 \%$. Selanjutnya pada diameter lobang saringan $20 \mathrm{~mm}$ panjang serat rata-rata $42 \mathrm{~mm}$, kisaran serat antara $40-60 \mathrm{~mm}$, dan persentase terbesar panjang serat rata-rata $50-60 \mathrm{~mm}$ sebesar $80 \%$.

\section{UCAPAN TERIMA KASIH}

Terima kasih kepada Politeknik Negeri Padang yang telah mendanai kegiatan ini melalui penelitian Unggulan Perguruan Tinggi dana DIPA Politeknik Negeri Padang dengan no. kontrak 190/PL9.1.4/PT.01.02/2019. Kemudian juga terima kasih kepada Bapak Tim Reviwer, teman-teman Staf Pengajar Jurusan Teknik Mesin Politeknik Negeri Padang dan Mahasiswa yang telah membantu dalam pembuatan dan perbaikan serta pengujian mesin ini.

\section{DAFTAR PUSTAKA}

Abral, H., Andriyanto, H.; Ilhamdi; Sapuan, S.M; Ishak, M.R. 2012. Mechanical Properties of Screw Pine (Pandanus Odoratissimus) Fiber-Unsaturated Polyester Composites, Polymer- 
Plastics Tecnology and Engineering, 51 (5) ; 500-506.

Darnoko., Guritno, P., Sugiharto, A., and Sugerti, S. 1995. "Pulping of Oil Palm Empty Fruit Bunches with Surpactant". in : Proc . Oil Palm Trunk and other Palm Wood, 83-87.

Deden. 2009. Seribu manfaat serat sawit. http://kafein4u.wordpress.com/2009 /02/28/seribu-manfaat-serat-sawit/ (6 February 2012)

[Dephut] Departemen Kehutanan. 2017. Statistik kehutanan Indonesia 20017.

Jinke Xu. 2010. Analysis and Design of Hemp Fibre Decorticators. A Thesis submitted to the Faculty of Graduate Studies of The University of Manitoba.

Junaidi, Anwar Kasim, Sir Anderson, Aidil Zamri., 2014. Pengembangan Mesin Pencacah Tandan Kosong Sawit (TKS) dengan Metode Pemotongan Sistem Crusher. Jurnal Polirekayasa No. 2 Vol. 10, April 2014. ISSN : 1858-3709.

Junaidi. 2015. Pengembangan Papan Komposit Dari Serat Tandan Kosong Kelapa Sawit (TKKS) Berperekat Gambir Berlapis Anyaman Bambu. Penelitian DIKTI, Skim Disertasi Doktor. No. Kontrak: 067 / PL9. 1.4 / LT / 2015

Junaidi. 2015. Pengembangan Mesin Pencacah Sampah/Limbah Plastik Dengan Sistem Crusher dan Silinder Pemotong Tipe Reel. POLI REKAYASA Volume 10, Nomor 2, April 2015

Junaidi, Anwar Kasim, Andrinal. 2016. Pengembangan Mesin Pengurai Serat Tandan Kosong Kelapa Sawit (TKKS) untuk Menghasilkan Serat
Mekanis. Jurnal Litbang Industri (No. Akreditasi: 558/AU1/P2MILIPI/09/2013) Vol. 6 No. 1, Juni 2016. p-ISSN 2252-3367.

Junaidi, Maimuzar, Alfian. 2017. Development of TKKS Fiber Enumerator Machine Hammer Mill System. Proceedings ICO ASCNITECH 2017.

Junaidi. 2018. Pengaruh Suhu dan Waktu Kempa Terhadap Sifat Fisik dan Mekanik Papan Komposit dari Serat TKKS Berperekat Gambir Berlapis Anyaman bambu. Jurnal Polirekayasa No. 2 Vol. 13, April 2018. ISSN : 1858-3709.

Karus. M., 2004. Use of natural fikers in composites in German automotive production 1996 till 2003, Nova Institut, German.

Kim, K.H. 1989. "Food Processing Equipment in Asia and The Pasific". Nordica International Limited Hongkong.

Kollman, F. F. P., E.W Kuenzi., and A. J Stamm. 1975. Principle of Wood Science and Technology. Wood Based Materials. Vol II. SpringerVerlag Berlin Heidelberg-New York.

Mardison. 2000. Rancang Bangun Pisau Pemotong Rumput Tipe Reel dengan Menggunakan Paket Program CAD (Skripsi). Bogor. Fakultas Teknologi Pertanian Bogor. Institut Pertanian Bogor.

Sitkey G. 1986. Mechanics of Agricultural Material. Elsevier. Amsterdam

Skeist, 1977. Hanbook of Adhesives. Van Nostrang Reinhod Company. Ney York. 
Sudrajat. 1979. Dasar-Dasar Teknologi Serat II. Institut Pertanian Bogor. Bogor.

Thieme, J.G. 1969. Coconut Oil Processing. FAO Rome

Wahyu KS. 2011. Desain Dan Kinerja Unit Pemotong Serasah Tebu Dengan Menggunakan Pisau Tipe Reel [tesis]. Program Pascasarjana, Institut Pertanian Bogor. Bogor. 